\title{
STRESS ANALYSIS OF ${ }^{+}$TYPE BEAM-COLUMN CONNECTIONS (II)
}

\author{
by Dr. GENGO MATSUI $\dagger$, and TOSHIO OKOSHI††
}

Members of A.I.J.

\section{$\S 4$ The axial load}

If the external forces act on each side as in fig. 3 , the next analytic function are considered;

$$
\begin{aligned}
& g(z)=\Sigma c_{m} z^{2 m}, \quad(m=0,1,2, \cdots) \\
& h(z)=\Sigma d_{m} z^{2 m},
\end{aligned}
$$

where $c_{m}$ and $d_{m}$ are unknown real constants which are determined from the external forces and their stress distribution on each side.

For $m=0$, it yields from (2.1) that

$$
\begin{aligned}
& \sigma_{x}{ }^{(0)}=c_{0}+0.5 d_{0}, \\
& \sigma_{y}{ }^{(0)}=c_{0}-0.5 d_{0}, \\
& \tau_{x y}{ }^{(0)}=0,
\end{aligned}
$$

where two unknown constants are determined only by the external forces on each side; the axial force $N_{1}$ acts on the side $A B$, then

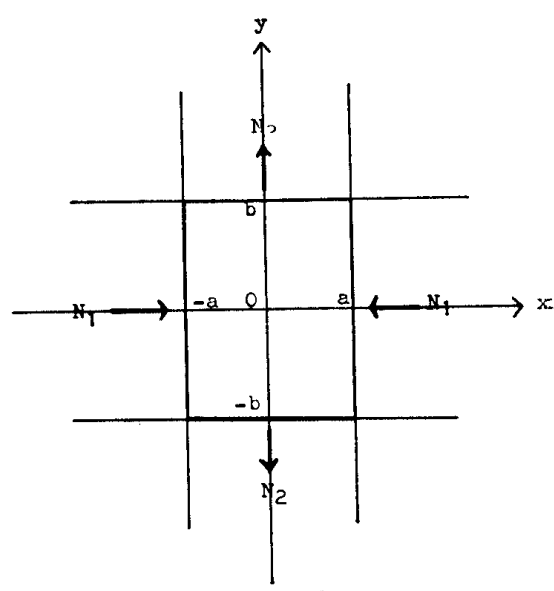

Fig. 3

$$
N_{1}=\left.\int_{-b}^{b} \sigma_{x}^{(0)}\right|_{x=a} \cdot d y
$$

so that

$$
\left.\sigma_{x}{ }^{(0)}\right|_{x=a}=\frac{N_{1}}{2} \frac{1}{b},
$$

and the axial force $N_{2}$ acts on $B C$, then

$$
N_{2}=\left.\int_{-a}^{a} \sigma_{y}{ }^{(0)}\right|_{y=b} \cdot d x
$$

so that

$$
\left.\sigma_{y}{ }^{(0)}\right|_{y=b}=\frac{N_{2}}{2} \frac{1}{a} .
$$

Substituting (4.3) and (4.4) into (4.2), $c_{0}$ and $d_{0}$ are determined.

This solution which is obtained only by the external forces is called the fundamental solution, or the $\mathbf{0}$-th approximate solution.

The $n$-th approximate solution is obtained in the similar method as $\S 3$.

For $m=n$ in (4.1), it yields form (2.1) that

$$
\begin{aligned}
& \sigma_{x}{ }^{(n)}=\sum_{m=0}^{n} \sum_{r=0}^{m}(-r)^{r}\left\{\left({ }_{2 m} C_{2 r}-2 m \times{ }_{2 m-1} C_{2 r+1} \times \frac{y^{2}}{x^{2}}\right) c_{m}+\frac{{ }_{2 m} C_{2 r}}{2} d_{m}\right\} x^{2 m-2 r} y^{2 r}, \\
& \sigma_{y}{ }^{(n)}=\sum_{m=0}^{n} \sum_{r=0}^{m}(-1)^{r}\left\{\left({ }_{2 m} C_{2 r}+2 m \times{ }_{2 m-1} C_{2 r+1} \times \frac{y^{2}}{x^{2}}\right) c_{m}-\frac{{ }_{2 m} C_{2 r}}{2} d_{m}\right\} x^{2 m-2 r} y^{2 r}, \\
& \tau_{x y}{ }^{(n)}=\sum_{m=0}^{n} \sum_{r=0}^{m}(-1)^{r+1}\left\{2 m \times{ }_{2 m-1} C_{2 r} c_{m}+\frac{{ }_{2 m} C_{2 r+1}}{2} d_{m}\right\} x^{2 m-2 r-1} y^{2 r+1} .
\end{aligned}
$$

The $2 n+2$ constants are determined by not only the external forces but also the distribution of the normal stress on each side. $E_{q}(4.5)$ yields two solutions depending on the latter.

$\dagger$ Prof. School of Scie. \& Eng., Waseda Univ.

it Member of Matsui Gengo Laboratory 
(1) If the axial force $N_{1}$ acts on the side $A B$, the distribution of the normal stress on $A B$ is selected to take $2 n$-th power of $y$;

$$
N_{1}=\left.\int_{-b}^{b} \sigma_{x}^{(n)}\right|_{x=a} \cdot d y
$$

so that

$$
\left.\sigma_{x}^{(n)}\right|_{x=a}=\frac{N_{1}}{2} \frac{2 n+1}{b^{2 n+1}} y^{2 n}
$$

And if the axial force $N_{2}$ acts on the side $B C$, it is selected to be linear of $y$.

$$
N_{2}=\left.\int_{-a}^{a} \sigma_{y}^{(n)}\right|_{y=b} d x,
$$

so that

$$
\left.\sigma_{y}{ }^{(n)}\right|_{y=b}=\frac{N_{2}}{2} \frac{1}{a}
$$

Substituting (4.6) and (4.7) into (4.5), then $c_{0}, d_{0}, \cdots, c_{n}$ and $d_{n}$ are determined.

(2) The distribution of the normal stress on the side $A B$ and $B C$ are interchanged with each other : for $N_{1}$ on $A B$, it is selected to be linear

$$
\left.\sigma_{x}^{(n)}\right|_{x=a}=\frac{N_{1}}{2} \frac{1}{b}
$$

and for $N_{2}$ on $B C$, it is $2 n$-th power degree with respect to $x$;

$$
\left.\sigma_{y}^{(n)}\right|_{y=b}=\frac{N_{2}}{2} \frac{2 n+1}{a^{2 n+1}} x^{2 n}
$$

For the case (1) the stresses (4.5) are represented by

$$
\sigma_{x}{ }^{(n)-X}, \sigma_{y}{ }^{(n)-X}, \tau_{x y}{ }^{(n)-X},
$$

and for the case (2)

$$
\sigma_{x}^{(n)-Y}, \sigma_{y}{ }^{(n)-X}, \tau_{x y}{ }^{(n)-Y} .
$$

We consider the following stresses :

$$
\sigma_{x}^{(n)-X}-\sigma_{x}^{(n-1)-X}, \sigma_{y}^{(n)-X}-\sigma_{y}^{(n-1)-X}, \tau_{x y}^{(n)-X}-\tau_{x y}{ }^{(n-1)-X},
$$

and

$$
\sigma_{x}{ }^{(n)-Y}-\sigma_{x^{(n-1)-Y}}, \sigma_{y}{ }^{(n)-Y}-\sigma_{y}{ }^{(n-1)-Y}, \tau_{x y}{ }^{(n)-Y}-\tau_{x y}{ }^{(n-1)-Y} \text {. }
$$

The expressions (4.10) and (4.11) have self-equilibrium of force, namely the external forces on each side are zero. The normal stress of (4.10) is zero on the side $B C$, and takes $(2 n-2)$-th and $2 n$-th power of $y$ on $A B$. But the normal stress of (4.11) is zero on the side $A B$, and takes $(2 n-2)$-th and $2 n$-th power of $x$ on $B C$.

Finaly

$$
\left.\begin{array}{l}
\sigma_{x}=\sigma_{x}{ }^{(0)}+\sum_{n=1}^{n} \lambda_{n}\left(\sigma_{x}{ }^{(n)-X}-\sigma_{x}{ }^{(n-1)-X}\right)+\sum_{n=1}^{n} \mu_{n}\left(\sigma_{x}{ }^{(n)-Y}-\sigma_{x}{ }^{(n-1)-Y}\right), \\
\sigma_{y}=\sigma_{y}{ }^{(0)}+\sum_{n=1}^{n} \lambda_{n}\left(\sigma_{y}{ }^{(n)-X}-\sigma_{y}{ }^{(n-1)-X}\right)+\sum_{n=1}^{n} \mu_{n}\left(\sigma_{y}{ }^{(n)-Y}-\sigma_{y}{ }^{(n-1)-Y}\right), \\
\tau_{x y}=\tau_{x y}{ }^{(0)}+\sum_{n=1}^{n} \lambda_{n}\left(\tau_{x y}{ }^{(n)-X}-\tau_{x y}{ }^{(n-1)-X}\right)+\sum_{n=1}^{n} \mu_{n}\left(\tau_{x y}{ }^{(n)-Y}-\tau_{x y}{ }^{(n-1)-Y}\right),
\end{array}\right\}
$$

where

$$
\begin{aligned}
& \sigma_{x}{ }^{(0)-X}=\sigma_{x}{ }^{(0)-Y}=\sigma_{x}{ }^{(0)}, \\
& \sigma_{y}{ }^{(0)-X}=\sigma_{y}{ }^{(0)-Y}=\sigma_{y}{ }^{(0)}, \\
& \tau_{x y}{ }^{(0)-X}=\tau_{x y}{ }^{(0)-Y}=\tau_{x y}{ }^{(0)}
\end{aligned}
$$

In this expression the 1 st term only is concerned with the external forces on each side, but the others have no concern with them and changes the stress distribution, and hence have influence on the strain potential energy. Therefore the moduli are determined to minimize the strain potential energy, so that

$$
\frac{\partial U}{\partial \lambda_{1}}=\cdots=\frac{\partial U}{\partial \lambda_{n}}=\frac{\partial U}{\partial \mu_{1}}=\cdots=\frac{\partial U}{\partial \mu_{n}}=0
$$

If the connection is square and the external forces on each side are equal, it follows that 


$$
\lambda_{n}=\mu_{n}
$$

Namely, directly, substituting (4.6) and (4.9) into (4.5), $c_{0}, d_{0}, \cdots, c_{n}$ and $d_{n}$ are determined. These stresses are represented by

$$
\sigma_{x}^{(n) X Y-}, \sigma_{y}^{(n)-X Y}, \tau_{x y}^{(n)-X Y},
$$

and we consider the following stresses :

$$
\sigma_{x}^{(n)-X Y}-\sigma_{x}^{(n-1)-X Y}, \sigma_{y}^{(n)-X Y}-\sigma_{y}^{(n-1)-X Y}, \tau_{x y}{ }^{(n)-X Y}-\tau_{x y}{ }^{(n-1)-X Y},
$$

which have self-equilibrium of force, namely the external forces on each side are zero, the distribution of the normal stress takes $(2 n-2)$-th and $2 n$-th power of $y$ on the side $A B$ and $x$ on $B C$. Finaly

$$
\left.\begin{array}{l}
\sigma_{x}=\sigma^{(0)}+\sum_{n=1}^{n} \nu_{n}\left(\sigma_{x}{ }^{(n)-X Y}-\sigma_{x}{ }^{(n-1)-X Y}\right), \\
\sigma_{y}=\sigma_{y}{ }^{(0)}+\sum_{n=1}^{n} \nu_{n}\left(\sigma_{y}{ }^{(n)-X Y}-\sigma_{y}{ }^{(n-1)-X Y}\right), \\
\tau_{x y}=\tau_{x y}{ }^{(0)}+\sum_{n=1}^{n} \nu_{n}\left(\tau_{x y}{ }^{(n)-X Y}-\tau_{x y}{ }^{(n-1)-X Y}\right),
\end{array}\right\}
$$

where

$$
\sigma_{x}{ }^{(0)-X Y}=\sigma_{x}^{(0)}, \sigma_{y}{ }^{(0)-X Y}=\sigma_{y}{ }^{(0)}, \tau_{x y}{ }^{(0)-X Y}=\tau_{x y}{ }^{(0)} .
$$

And similarly

$$
\frac{\partial U}{\partial \nu_{1}}=\cdots=\frac{\partial U}{\partial \nu_{n}}=0
$$

In this way, the true solution of the rectangular beam-column connection as a rectangular plate under the axial load in fig. 3 is obtained to take $m$ in (4.1) to infinite, applying the principle of least energy.

Abridging this regular method, DIRECTLY, we can obtain the solution, if we do not mind the troublesome, Namely, in eqs (4.5) there are $2 n+2$ constants which are determined by the external forces and the principle of least energy; from the former, 2 constants are determined :

$$
\left.\begin{array}{l}
c_{0}=f_{1}\left(c_{1}, d_{1}, \cdots, c_{n}, d_{n}\right), \\
d_{0}=f_{2}\left(c_{1}, d_{1}, \cdots, c_{n}, d_{n}\right),
\end{array}\right\}
$$

then the strain potential energy is

$$
U=U\left(c_{1}, d_{1}, \cdots, c_{n}, d_{n}\right) \text {, }
$$

from the the later the remaining constants are determined :

$$
\frac{\partial U}{\partial c_{1}}=\frac{\partial U}{\partial d_{1}}=\cdots=\frac{\partial U}{\partial c_{n}}=\frac{\partial U}{\partial d_{n}}=0
$$

\section{$\$ 5$ The symmetrical load with respect to the $y$-axis}

If the external forces acts on each side as in fig. 4, the next analytic functions are considered;

$$
\begin{aligned}
& g(z)=i \sum c_{m} z^{2 m-1}, \\
& h(z)=i \sum d_{m} z^{2 m-1},
\end{aligned} \quad(m=1,2,3, \cdots)
$$

where $c_{m}$ and $d_{m}$ are unknown real constants.

For $m=1$ the stresses of (5.1) yied from (2.1) that

$$
\begin{aligned}
& \sigma_{x}{ }^{(0)}=-\left(2 c_{1}+0.5 d_{1}\right) y, \\
& \sigma_{y}{ }^{(0)}=0.5 d_{1} y, \\
& \tau_{x y}{ }^{(0)}=-0.5 d_{1} x
\end{aligned}
$$

where two unknown constants are determined from only the external forces, namely, if the bending moment $M_{1}$ acts on the side $A B$, then

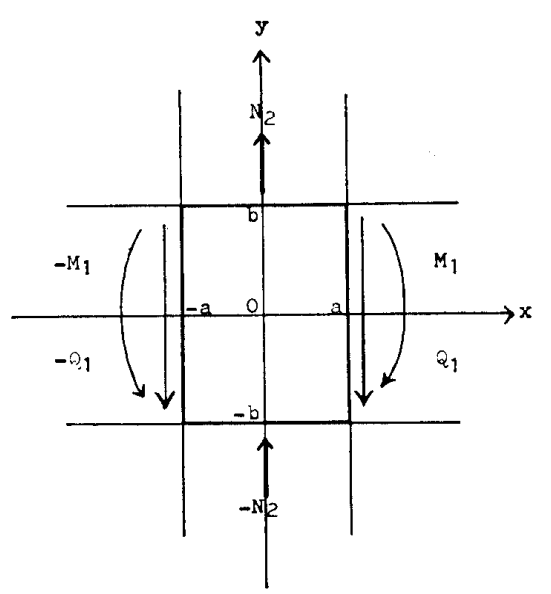

Fig. 4

$$
M_{1}=\left.\int_{-b}^{b} \sigma_{x}^{(0)}\right|_{x=a} \cdot y d y
$$

so that

$$
\left.\sigma_{x}^{(0)}\right|_{x=a}=\frac{M_{1}}{2} \frac{3}{b^{3}} y,
$$


and if the axial force $N_{2}$ acts on $B C$, then

$$
N_{2}=\left.\int_{-a}^{a} \sigma_{y}{ }^{(0)}\right|_{y=b} \cdot d x
$$

so that

$$
\left.\sigma_{y^{(0)}}\right|_{y=b}=\frac{N_{2}}{2} \frac{1}{a}
$$

Substituting (5.3) and (5.4) into (5.2), $c_{1}$ and $d_{1}$ are determined

Then $n$-th approximate solution is obtained in the similar way as the previous sections.

For $m=n+1$ in (5.1), it follows from (2.1) that

$$
\begin{aligned}
& \left.\sigma_{x}{ }^{(n)}=\sum_{m=1}^{n+1} \sum_{r=0}^{m}(-1)^{r+1}\left\{{ }_{2 m-1} C_{2 r+1}+(2 m-1) \times_{2 m-2} C_{2 r}\right) c_{m}+\frac{{ }_{2 m-1} C_{2 r+1}}{2} d_{m}\right\} x^{2 m-2 r-2} y^{2 r+1}, \\
& \sigma_{y}{ }^{(n)}=\sum_{m=1}^{n+1} \sum_{r=0}^{m}(-1)^{r+1}\left\{\left(_{2 m-1} C_{2 r+1}-(2 m-1) \times_{2 m-2} C_{2 r}\right) c_{m}-\frac{2 m-1}{2} C_{2 r+1} d_{m}\right\} x^{2 m-2 r-2} y^{2 r+1} \\
& \tau_{x y}{ }^{(n)}=\sum_{m=1}^{n+1} \sum_{r=0}^{m}(-1)^{r}\left\{(2 m-1) \times_{2 m-2} C_{2 r+1} c_{m} \times \frac{y^{2}}{x^{2}}-\frac{2 m-1}{2} C_{2 r} d_{m}\right\} x^{2 m-2 r-1} y^{2 r}
\end{aligned}
$$

From which two solutions are obtained depending on the distribution of the normal stress on each side.

(1) For $M_{1}$ on the side $A B$, the distribution of the normal stress on $A B$ is selected to take ( $2 n$ +1 ) - th power;

$$
\left.\sigma_{x}^{(n)}\right|_{x=a}=\frac{M_{1}}{2} \frac{2 n+3}{b^{2 n+3}} y^{2 n+1}
$$

and for $N_{2}$ on the side $B C$, it is linear

$$
\left.\sigma_{y}{ }^{(n)}\right|_{y=b}=\frac{N_{2}}{2} \frac{1}{a}
$$

Substituting (5.6) and (5.7) into (5.5), then $c_{1}, d_{1}, \cdots, c_{n+1}$ and $d_{n+1}$ are determined.

(2) For $M_{1}$ on the side $B C$, it is linear:

$$
\left.\sigma_{x}{ }^{(n)}\right|_{x=a}=\frac{M_{1}}{2} \frac{3}{b^{3}} y,
$$

and for $N_{2}$ on the side $B C$, it is $2 n$-th power:

$$
\left.\sigma_{y}^{(n)}\right|_{y=b}=\frac{N_{1}}{2} \frac{2 n+1}{a^{2 n+1}} x^{2 n}
$$

Substituting (5.8) and (5.9) into (5.5), then $c_{1}, \dot{d}_{1}, \cdots, c_{n+1}$ and $d_{n+1}$ are determined.

For the case (1) the stresses are represented by

$$
\sigma_{x}^{(n)-X}, \sigma_{y}{ }^{(n)-X}, \tau_{x y^{(n)-X}},
$$

and for the case (2)

$$
\sigma_{x}^{(n)-Y}, \sigma_{y}^{(n)-Y}, \tau_{x y}{ }^{(n)-Y}
$$

And finaly we consider the equations as eqs (4.12) and (4.13). Then the last eqs (4.12) are the $n$-th approximate solution.

Also, directly, we can obtain the solution from (5.5): by the external forces, two constants are determined :

$$
\left.\begin{array}{l}
c_{1}=f_{1}\left(c_{2}, d_{2}, \cdots, c_{n+1}, d_{n+1}\right), \\
d_{1}=f_{2}\left(c_{2}, d_{2}, \cdots, c_{n+1}, d_{n+1}\right),
\end{array}\right\}
$$

then the strain potential energy is

$$
U=U\left(c_{2}, d_{2}, \cdots, c_{n+1}, d_{n+1}\right),
$$

from the principle of least energy the remaining constants are determined :

$$
\frac{\partial U}{\partial c_{2}}=\frac{\partial U}{\partial d_{2}}=\cdots=\frac{\partial U}{\partial c_{n+1}}=\frac{\partial U}{\partial d_{n+1}}=0
$$

\section{$\$ 6$ The symmetrical load with respect to the $X$-axis}

This type is the same one as $\S 5$, but $x$ and $y$ are interchanged with each other (see fig. 4 and 5 ). Then 


$$
\begin{aligned}
& g(z)=\sum c_{m} z^{2 m-1}, \\
& h(z)=\sum d_{m} z^{2 m-1},
\end{aligned} \quad(m=1,2,3, \cdots)
$$

where $c_{m}$ and $d_{m}$ are real numbers.

The fundamental solution, or the $o$-th approximate solution is obtained for $m=1$ in (6.1);

$$
\begin{aligned}
& \sigma_{x}{ }^{(0)}=\left(c_{1}+0.5 d_{1}\right) x, \\
& \sigma_{y}{ }^{(0)}=\left(c_{1}-0.5 d_{1}\right) x, \\
& \tau_{x y}{ }^{(0)}=-\left(c_{1}+0.5 d_{1}\right) y,
\end{aligned}
$$

where $c_{1}$ and $c_{1}$ are determined from

$$
\left.\sigma_{x}{ }^{(0)}\right|_{x=a}=\frac{N_{1}}{2} \frac{1}{b}
$$

and

$$
\left.\sigma_{y}^{(0)}\right|_{y=b}=-\frac{M_{2}}{2} \frac{3}{a^{3}} x .
$$

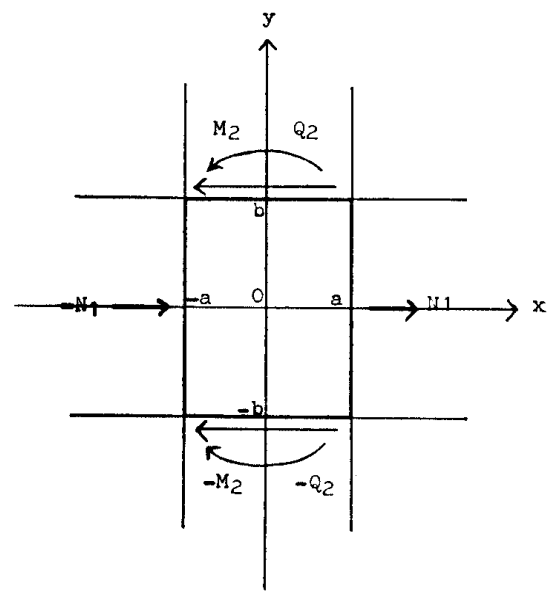

Fig. 5

For $m=n+1$ in $(6.1)$

$$
\begin{aligned}
& \sigma_{x}{ }^{(n)}=\sum_{m=1}^{n+1} \sum_{r=0}^{m}(-1)^{r}\left\{\left({ }_{2 m-1} C_{2 r}-(2 m-1) \times_{2 m-2} C_{2 r+1} \times \frac{y^{2}}{x^{2}}\right) c_{m}+\frac{2 m-1}{2} C_{2 r}\right. \\
& \left.\sigma_{m}\right\} x^{2 m-2 r-1} y^{2 r}, \\
& \left.\sigma_{y}{ }^{(n)}=\sum_{m=1}^{n+1} \sum_{r=0}^{m}(-I)^{r}\left\{\left({ }_{2 m-1} C_{2 r}+(2 m-1) \times_{2 m-2} C_{2 r+1} \times \frac{y^{2}}{x^{2}}\right) c_{m} \times\right\}-\frac{2 m-1}{2} C_{2 r} d_{m}\right\} x^{2 m-2 r-1} y \\
& \tau_{x y}{ }^{(n)}=\sum_{m=1}^{n+1} \sum_{r=0}^{m}(-1)^{r+1}\left\{(2 m-1) \times_{2 m}{ }_{2} C_{2 r} c_{m}+\frac{2 m-1}{2} C_{2 r+1} d_{m}\right\} x^{2 m-2 r-2} y^{2 r+1},
\end{aligned}
$$

where the unknown constants are determined from

(1) $\left.\sigma_{x^{(n)}}\right|_{x=a}=\frac{N_{1}}{2} \frac{2 n+1}{b^{2 n+1}} y^{2 n}$,

$$
\left.\sigma_{y}{ }^{(n)}\right|_{y=b}=\frac{M_{2}}{2} \frac{3}{a^{3}} x
$$

or from

$$
\begin{aligned}
& \left.\sigma_{x}{ }^{(n)}\right|_{x=a}=\frac{N_{1}}{2} \frac{1}{b} \cdots \cdots \cdots \cdots . . . . . \\
& \left.\sigma_{y}{ }^{(n)}\right|_{y=b}=\frac{M_{2}}{2} \frac{2 n+3}{a^{2 n+3}} x^{2 n+1}
\end{aligned}
$$

After this we omit, becase of the same as $\S 5$.

\section{$\S 7$ Dsiplacement}

For the Yokota formula the displacement $u$ in $x$ direction is represented by

$$
E u=-(1+\nu) y I_{m}[g(z)]+(1-\nu) \operatorname{Re}\left[\int g(z) d z\right]+\frac{1+\nu}{2} \operatorname{Re}\left[\int h(z) d z\right],
$$

and displacement $v$ in $y$ direction is represented by

$$
E v=-(1+\nu) y \operatorname{Re}[g(z)]+2 I_{m}\left[\int g(z) d z\right]+2 I_{m}\left[\int g(z) d z\right]-\frac{1+\nu}{2} I_{m}\left[\int h(z) d z\right] \text {. }
$$

Now we show the displacement of $n$-th solution, namely eqs (3.35), (4.5), (5.5) and (6.5); for the inverse-symmetrical load, it follows from (2.3) that

$$
\begin{aligned}
& E u^{(n)}=\sum_{m=0}^{n+1} \sum_{r=0}^{m}(-1)^{r+1}\left[\left\{(1+\nu)_{2 m} C_{2 r}+(1-\nu) \frac{2 m+1}{2 m+1} C_{2 r+1}\right\} c_{m}+\frac{1+\nu}{2} \frac{2 m+1}{2 m+1} C_{2 r+1} d_{m}\right] x^{2 m-2 r} y^{2 r+1} \\
& E v^{(n)}=\sum_{m=0}^{n+1} \sum_{r=0}^{m}(-1)^{r}\left[\left\{(1+\nu)_{2 m} C_{2 r+1} \times \frac{y^{2}}{x^{2}}+2 \frac{2 m+1}{2 m+1} C_{2 r}\right\} c_{m}-\frac{1+\nu}{2} \frac{2 m+1}{2 m+1} C_{2 r} d_{m}\right] x^{2 m-2 r+1} y^{2 r}
\end{aligned}
$$

for the axial load, it follows from (2.4) that

$$
E u^{(n)}=\sum_{m=0}^{n} \sum_{r=0}^{m}(-1)^{r}\left[\left\{-(1+\nu)_{2 m} C_{2 r+1} \times \frac{y^{2}}{x^{2}}+(1-\nu) \frac{2 m+1}{2 m+1}\right\} C_{m}+\frac{1+\nu}{2} \frac{2 m+1}{2 m+1} C_{2 r} d_{m}\right] x^{2 m-2 r+1} y^{2 r}
$$




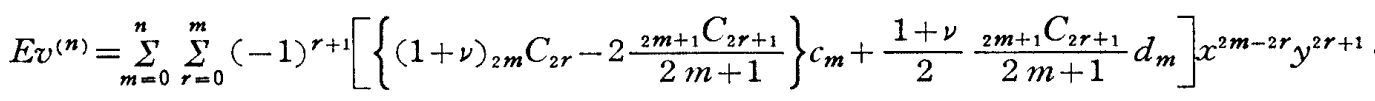

for the symmetrical load with respect to the $y$-axis

$$
\begin{aligned}
& E u^{(n)}=\sum_{m=1}^{n+1} \sum_{r=0}^{m}(-1)^{r+1}\left[\left\{(1+\nu)_{2 m-1} C_{2 r}+(1-\nu) \frac{2 m C_{2 r+1}}{2 m}\right\} c_{m}+\frac{1+\nu}{2} \frac{{ }_{2 m} C_{2 r+1}}{2 m} d_{m}\right] x^{2 m-2 r-1} y^{2 r+1} \\
& E \mathcal{V}^{(n)}=\sum_{m=1}^{n+1} \sum_{r=0}^{m}(-1)^{r}\left[\left\{(1+\nu)_{2 m-1} C_{2 r+1} \times \frac{y^{2}}{x^{2}}+2 \frac{2 m C_{2 r}}{2 m}\right\} c_{m}-\frac{1+\nu}{2} \frac{{ }_{2 m} C_{2 r}}{2 m} d_{m}\right] x^{2 m-2 r} y^{2 r}
\end{aligned}
$$

for the symmetrical load with respect to the $x$-axis

$$
\begin{aligned}
& E u^{(n)}=\sum_{m=1}^{n+1} \sum_{r=0}^{m}(-1)^{r}\left[\left\{-(1+\nu)_{2 m-1} C_{2 r+1} \times \frac{y^{2}}{x^{2}}+(1-\nu) \frac{2 m}{2 m}\right\} c_{m}+\frac{1+\nu}{2} \cdot \frac{{ }_{2 m} C_{2 r}}{2 m} d_{m}\right] x^{2 m-2 r} y^{2 r} \\
& E \mathcal{v}^{(n)}=\sum_{m=1}^{n+1} \sum_{r=0}^{m}(-1)^{r+1}\left[\left\{(1+\nu)_{2 m-1} C_{2 r}-2 \frac{2 m}{2 m} C_{2 r+1}\right\} c_{m}+\frac{1+\nu}{2} \frac{{ }_{2 m} C_{2 r+1}}{2 m} d_{m}\right] x^{2 m-2 r-1} y^{2 r+1} \ldots
\end{aligned}
$$

Then the origin does not displace :

$$
\left.\begin{array}{l}
u(x=0, y=0)=0 \\
v(x=0, y=0)=0
\end{array}\right\}
$$

\section{$\S 8$ Example}

We solve the most important type for us, namely the inverse-symmetrical load, because there is little space left. The problem is as follows (see fig. 2);

$$
\begin{aligned}
& a=b=1 \mathrm{~cm} \\
& Q_{1}=Q_{2}=5.556 \mathrm{~kg} \\
& \left.M_{1}=M_{2}=-25.31 \mathrm{~kg} \cdot \mathrm{cm}\right\}
\end{aligned}
$$

From eqs (3.3) and (3.4) and (3.5), eq (3.2) yields that

$$
\left.\begin{array}{l}
\sigma_{x}{ }^{(0)}=-37.96 x y, \\
\sigma_{y}{ }^{(0)}=-37.96 x y, \\
\tau_{x y}{ }^{(0)}=-22.53+18.98 x^{2}+18.98 y^{2},
\end{array}\right\}
$$

which is the fundamental solution, or the $o$-th approximate solution.

From eqs (3.7) and (3.11) and (3.9), eq (3.6) yields that

$$
\left.\begin{array}{l}
\sigma_{x}{ }^{(1)-X Y}=-63.27 x y+63.27 x^{3} y-63.27 x y^{3}, \\
\sigma_{y}{ }^{(1)-X Y}=-63.27 x y-63.27 x^{3} y+63.27 x y^{3}, \\
\tau_{x y^{(1)}-X Y}=-26.75+31.64 x^{2}+31.64 y^{2}+15.82 x^{4}-94.91 x^{2} y^{2}+15.82 y^{4}
\end{array}\right\}
$$

Then eq (3.18) yields that

$$
\left.\begin{array}{l}
\sigma_{x}{ }^{(1)-X Y}-\sigma_{x}{ }^{(0)}=-25.31 x y+63.27 x^{3} y-63.27 x y^{3}, \\
\sigma_{y}{ }^{(1)-X Y}-\sigma_{y}{ }^{(0)}=-25.31 x y-63.27 x^{3} y+63.27 x y^{3} \\
\tau_{x y}{ }^{(1)-X Y}-\tau_{x y}{ }^{(0)}=-4.22+12.66 x^{2}+12.66 y^{2}+15.82 x^{4}-94.91 x^{2} y^{2}+15.82 y^{4}
\end{array}\right\}
$$

From eqs (8.3) and (8.5), the 1 st approximate solution (3.19) is obtained;

$$
\left.\begin{array}{l}
\sigma_{x}=-37.96 x y+\nu_{1}\left(-25.21 x y+63.27 x^{2} y-63.27 x y^{3}\right), \\
\sigma_{y}=-3796 x y+\nu_{1}\left(-25.31 x y-63.27 x^{3} y+63.27 x y^{3}\right), \\
\tau_{x y}=-22.53+18.98 x^{2}+18.98 y^{2}+\nu_{1}\left(-4.22+12.66 x^{2}+12.66 y^{2}+15.82 x^{4}-94.91 x^{2} y^{2}+15.82 y^{4}\right),
\end{array}\right\}
$$

where $\nu_{1}$ is obtained from $(3.20)$;

$$
\nu_{1}=-\frac{3.16-3.25 \nu}{26.46-20.97 \nu}
$$

so that

$$
\left.\begin{array}{l}
\nu_{1}=-0.099(\nu=0.1) \\
\nu_{1}=-0.067(\nu=0.3) .
\end{array}\right\}
$$

For $\nu=0.1$, the 1 st approximate solution yield that 


$$
\left.\begin{array}{l}
\sigma_{x}=-35.43 x y-6.33 x^{3} y+6.33 x y^{3}, \\
\sigma_{y}=-35.43 x y+6.33 x^{3} y-6.33 x y^{3}, \\
\tau_{x y}=-22.11+17.71 x^{2}+17.71 y^{2}-1.58 x^{4}+9.49 x^{2} y^{2}-1.58 y^{4}
\end{array}\right\}
$$

See fig. 6 .
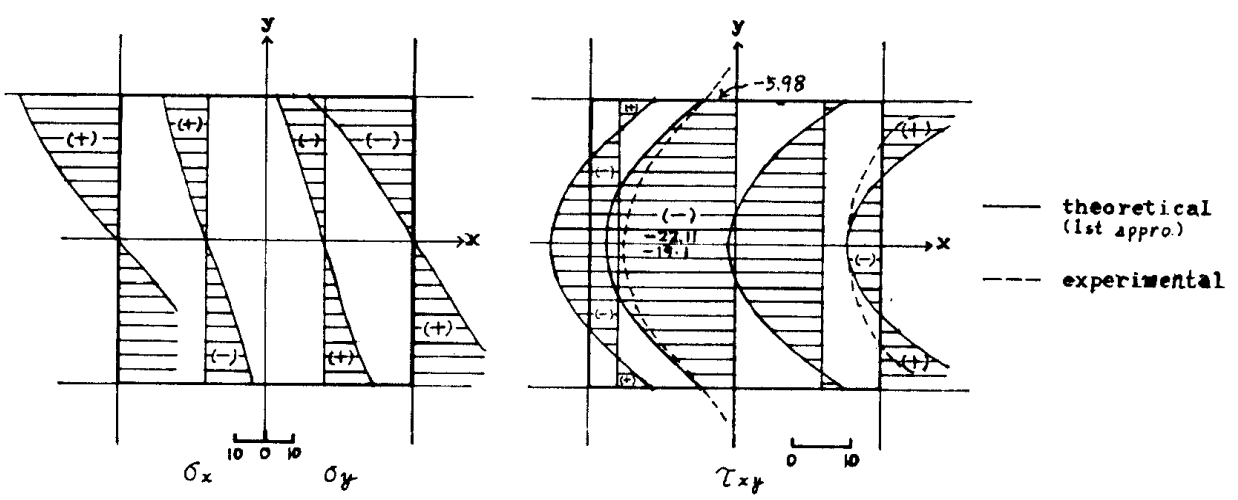

Fig. 6

It is known from this example that : the stresses near the center are not so different from the fundamental solusion, but near the corner, the more the stresses of self-equilibrium are taken, the more they change. See STRESS ANALYSIS OF + TYPE BEAM-COLUMN CONNECTIONS (III).

\section{\$9 Conclusion}

In this method, we divide the solution into a particular solution which satisfies the external forces and serial general solutions which satisfy the non-existence of the external forces; namely a particular solution of an inhomogeous equation and serial solutions of its homogeneous equation in Galerkin method.

\section{REFERENCES}

1) Bezuhof, Teoretical Elasticity and Plasticity, Maruzen

2) Akimasa Ono, Strength of Material, Maruzen, 1938

3) G. Matsui \& Y. Tsuboi, On the Slabs Reinforced by Ribs Subjected to Horizontal Shear Force, Recent Researchs of Structural Mechanics, Prof. Tsuboi Anniversary Volume, Uno-shoten, 1968

4) K. Washizu, Variational Methods in Elasticity and Plasticity, Pergamon Press, 1968

5) G. Matsui, Strength of Material, Shokoku-sha, 1967

6) A.E. Green \& J.E. Adkins, Large Elastic Deformation, Oxford, 1960 


\section{十型梁・柱接合部の応力解析 (II) (梗概)}

\section{$\S 4$ 軸荷 重}

外力が図一-3のように作用するとき, 解析関数を式 (4.1)のように取る。 $m=1$ に対して, 灾力は式 (4.2) に なり，二つの未知定数が，外力のみによって満足される ので, 基本解または 0 次近似解となる。前節と同様にし て, 自己釣合の応力系を低次から順次選んで高次の近似 解を得る。正解壮それらを無限に選ぶことによって得ら れる。また，これらの解は式 (4.5) からわかるように， 直接近似解を得ることができる。すなわち， $m=n$ に対 して, 未知定数は $n+2$ 個ある。外力を満足するように 二つの未知定数は $n$ 個の未知定数によって表わされる。 このとき，この歪ポテンシャル・エネルギーは $2 n$ 個の 未知定数によって表わされ，これらの未知定数は，エネ ルギーの最小原理により決定される：式 (4.20).

接合部が 正方形で，外力が等しければ，式 (4.15) を 使って得られる。

\section{$\S 5 y$ 軸対称荷重 \\ $\S 6 x$ 軸対称荷重}

问様にして，基本解に順次自己釣合の応力系に係数を かけ合わせたものを加え, エネルギーの最小原理にした がって，それらの係数を決定することによって得られ る。また，直接法化よっても得られる。

\section{$\S 7$ 変 位}

* 早稻田大学教授・工榑

** 松井源吾研究空

(昭和 44 年 7 月 15 日本橋受理・剖論期限昭和 45 年 6 月末日)

$\begin{array}{lllll}\text { 正会只 } & \text { 松 } & \text { 井 } & \text { 源 } & \text { 吾* } \\ \text { 正会員 } & 大 & \text { 越 } & \text { 俊 } & \text { 男** }\end{array}$

標田方程式に対して， $x$ 方向の変位には式 (7.1)で, また， $y$ 方向の変位vでは式 (7.2) で示される。ここで は，各型で， $n$ 次近次解を得るために，基本式に $m$ を 代入した忘力に対応寸る変位を式 (7.3) から式 (7.10) で与えた。これらの変位式で，原点が不動点になる。

\section{$\S 8$ 例 題}

紙面の都合で，逆対称荷重についてのみ扱い，光弾性 の実験による值と比較した。問題は正方形接合部で，各 辺で同じ大きさの外力を与えたものとした：式 (8.1) と 式 (8.2)。基本解は (8.3) で表わさ礼る。式 (8.4) 法各 辺で直応力は 3 次関数のみで，かつ，外力を満足してい る解になる。式 (8.4) から,式 (8.3) を引くと, 式 (8.5) の最も低次の自己釣合の応力系が得られる。これに係数

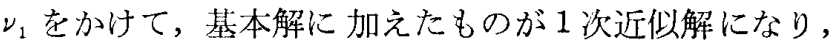
係数 $\nu_{1}$ は歪ポテンシャル・エネルギーを最小になるよ うに決定される，すなわち，式 (8.7)。図 6 参照。

この例題でわかるように，中心部の忘力は基本解と比 較して大差ないが，隅の応力は，自己釗合の応力系を多 く取るほど変化してゆく・

\section{\$9 ま と}

この方法では, 解を外力を满足する一つの特殊解と, 外力不存在条件（力の自己釣合）を満足する級数の型の 一般解とに分けた。すなわち，これはガラーキン法にお ける, 非同次方程式の一つの特殊解々その同次式の級数 の型の一般解上の和による解上類似のものである。 


\title{
VIBRATION AND STATIC LOADING TEST OF HACHINOHE TECHNICAL COLLEGE
}

NO. 2-Static Loading Tests-

(See Page 41)

by Dr. HIROYUKI AOYAMA, Assoc. of Prof. of Tokyo Univ., SHUNSUKE SUGANO, Groduate Student of Tokyo Univ, and SHUNSUKE NAKATA, Graduate Student of Tokyo Univ, Members of A.I.J.

U.D.C. $624.078: 624.071 .3$

\author{
STRESS ANALYSIS OF + TYPE BEAM - COLUMN \\ CONECTION (II) (See Page 43)
}

by Dr. GENGo MATSUI, Prof. of Waseda Univ. and TOSHIO OGOSHI, Graduate Student of Waseda Unive. Members of A.I.J.

U.D.C. $624.0145: 539.4$

\section{INELASTIC BEHAVIORS OF STRUCTURAL STEEL SECTIONS UNDER ALTERNATIVE LOADING}

(See Page 53)

(1) Method of Analysis and Examples

by Dr. SADAYOSHI IGRASHI, Prof. Osaka Univ., CHIAKI MATSUII, Lecturer of $\mathrm{K}_{y}$ ushu Univ., KOGII YOSHIMURA, K. MATSUMURA Graduate Student of Kyushu Univ. Members of A.I.J.

U.D.C. 624.042 .7

A NOTE ON ESTIMATION OF PROBABLE ACCETLRATIONS IN BEDROCK (See Page 63)

by Dr. HIROSHI TAGIME. Prof. of Nihon Univ. Member of A.I.J.

U.D.C. 628.921

DAYLIGHTING CALCULATION BY LUMINOUS FLUX TRANSFER METHOD

(Interreflection Method)

by KOZO ISHINO, Assistant of Nagoya Univ. and MASAYUKI IIZUKA, Prof. of Nagoya Univ., Members of .A.I.J.

\footnotetext{
Many studies of interreflection based upon the mathematical analysis and experimental data have been made in the idealized rooms. Luminous Analogue Computer, which was originated with O'Brien in the Department of Engineering, University of California or digital computer may be employed for the solution of simultanous equations which describe the interreflection systems. These computers are applied for the prediction of interior illumination or daylighting calculation and the analysis of heat transfer problem. As already published by O'Brien, the percent error of the analogue solution relative to the digital solution results from inaccurate settings of the resistances and errors in the potentiometer or galvanometer readings, but its difference is very few. The predetermination of daylighting design is based upon the many independent element or variables. (ex. room geometry; room properties and characteristics which involve reflectance; location and size of lighting window, limitation of depth, effect of interreflection; construction and material of window; block planning etc.)

In this paper, daylighting design problem of an idealized room with a unilateral lighting window is solved by computer, in regard to the fundamental analytical data such as luminous emittance ratio, direct and total illumination. Moreover, using the point-by-point method, direct and total illumination distribution of the floor are calculated and compared.
} 